\title{
Large-scale manipulations reveal that top-down and bottom-up controls interact to alter habitat utilization by saltmarsh fauna
}

\author{
David Samuel Johnson ${ }^{1, *}$, John W. Fleeger ${ }^{1}$, Linda A. Deegan ${ }^{2}$ \\ 1202 Life Sciences Building, Department of Biological Sciences, Louisiana State University, Baton Rouge, \\ Louisiana 70803, USA \\ ${ }^{2}$ The Ecosystems Center, Marine Biological Laboratory, 7 MBL Street, Woods Hole, Massachusetts 02543, USA
}

\begin{abstract}
We used ecosystem-wide predator removal and nutrient enrichment to examine topdown and bottom-up forces on saltmarsh fauna. We reduced the killifish Fundulus heteroclitus by $\sim 60 \%$, which elicited significant increases ( 2 to $4 \times$ ) in hydrobiid snails Hydrobia spp., suggesting topdown control. The talitrid amphipod Uhlorchestia spartinophila was the most abundant species of epifauna in the creek-bank Spartina alterniflora habitat. Our elevated water column nutrients $\left(\sim 70 \mu \mathrm{mol} \mathrm{l} \mathrm{l}^{-1}, \sim 10 \times\right.$ background) and predator reduction treatments alone both yielded nonsignificant increases in amphipod abundance, suggesting weak top-down and bottom-up control over this species. However, treatments interacted antagonistically in this habitat such that amphipod abundances were lower than would be expected by an additive response to both treatments. We found corresponding amphipod abundance increases in the adjoining creek-wall habitat, suggesting that amphipods move under the influence of our treatments from the marsh edge onto the creek wall, possibly as a result of an increased incidence of a parasitic (i.e. trematode Levinseniella sp.) infection. Coincident to increased amphipods on creek walls, semipalmated sandpipers Calidris pusilla, amphipod predators, increasingly foraged in creek channels in combined treatments $(\sim 30 \times$ higher than controls based on unreplicated creek systems). Our results suggest that top-down and bottom-up effects may at times be difficult to detect in small, single-factor studies because of inter-habitat movements of target species and redundant predation. Because the effects of stressors may not be limited to one part of the landscape even for small, motile fauna, landscape-level studies may generally be needed to capture responses to anthropogenic activities.
\end{abstract}

KEY WORDS: Ecosystem experiments $\cdot$ Multi-stressors $\cdot$ Parasites $\cdot$ Epifauna $\cdot$ Salt marsh

\section{INTRODUCTION}

Predicting how ecosystems respond to anthropogenic perturbations is of great interest to ecologists. Two anthropogenic activities that impact many aquatic systems - often concurrently-are nutrient loading (e.g. land-derived nutrients) and food web alterations (e.g. predator removal) (Deegan et al. 2007). These anthropogenic activities simultaneously embody the classic ecological debate over whether the functioning or community structure of ecosystems is regulated by top-down (consumer driven) or bottom-up (resource driven) processes (Hairston et al. 1960, Power 1992). Understanding how these processes operate is critical in predicting how ecosystems respond to human activities.

Top-down and/or bottom-up processes may operate independently (Posey et al. 1999, 2002) or interactively (Russell \& Connell 2005) in marine systems. Because predictions about interactive effects cannot be made by examining each process in isolation, it is important to examine both effects simultaneously. Another difficulty in predicting top-down and bottom-up effects is that they may vary across the landscape (Fleeger et al. 
2008). Predictions about top-down and bottom-up effects on the entire ecosystem based on plot-level experiments, which are typically conducted in one part of the landscape (e.g. Posey et al. 2002), may therefore only be applicable to that habitat (Fleeger et al. 2008).

Benthic macroinvertebrates are consumers of primary production and prey for higher trophic levels. Previous studies have demonstrated that saltmarsh infauna (sediment-dwelling invertebrates such as annelids) are regulated by both top-down and bottom-up factors (Posey et al. 1999, 2002, Deegan et al. 2007). However, the effects of these factors on epifauna (surfacedwelling invertebrates such as amphipods) remains relatively unknown, possibly because, due to their mobility, large-scale manipulations are required to effectively capture epifauna responses. Top-down control of epifauna such as amphipods may be exerted by the killifish Fundulus heteroclitus L. (Kneib 1982, Allen et al. 1994, Fell et al. 1998), a common predator in the tidal marshes of the western Atlantic (Allen et al. 1994). Topdown control may also be exerted on epifauna by aerial predators (i.e. birds). For instance, shorebirds in the Bay of Fundy exert top-down control on the amphipod Corophium volutator during low tide (Wilson 1991). Because birds may have access to exposed epifauna at low tide and fish may have access to epifauna during inundation periods, an indirect interaction between fish and bird predators may exist (Crowder et al. 1997). Benthic microalgae, an epifaunal food source, which responds rapidly to nitrogen input with increased biomass and/or productivity (Sarda et al. 1998), may exert bottom-up control on epifauna. Epifauna such as amphipods commonly exert top-down control on algae in marine systems (Duffy \& Hay 2000), and may be important algal consumers in salt marshes.

We present the results of whole-ecosystem manipulations of key predator (Fundulus heteroclitus) removal (top-down) and nutrient addition (bottom-up) on saltmarsh epifauna. Our results represent traditional examination of top-down and bottom-up influences on the abundances of saltmarsh invertebrates (e.g. Posey et al. 1999), where density changes may result from altered survivorship or reproductive success of a species (whether from reduced predation pressure or increased food supply). Here we focus on individual taxon responses instead of ecosystem or community responses because individual taxa may vary in their response to top-down and bottom-up factors (Posey et al. 1999, 2002, Fleeger et al. 2008). The scale of our experiments allowed us to examine possible treatment-induced movements of epifauna across the landscape. As a result of treatments, we found that amphipods moved from vegetated to unvegetated habitats, which, in turn, increased susceptibility to a rarely encountered predator, Calidris pusilla, a migratory shorebird. This was an unexpected consequence observable only in a wholeecosystem study because of the area needed to influence bird behavior.

\section{MATERIALS AND METHODS}

Study site. The present study was conducted during 2 growing seasons (May to September in 2005 and 2006) in tidal creeks in the Plum Island Estuary (PIE), Massachusetts. These creeks are all located within the broader salt marsh that lines the $14.5 \mathrm{~km}$ Rowley River estuary $\left(42^{\circ} 44^{\prime} \mathrm{N}, 70^{\circ} 52^{\prime} \mathrm{W}\right)$, which opens into Plum Island Sound approximately $7 \mathrm{~km}$ inland from where Plum Island Sound enters the Atlantic Ocean. Eight first-order (primary) creeks were selected for treatments and similar creeks were paired. Creeks were 300 to $500 \mathrm{~m}$ long, 4.1 to $7.5 \times 10^{6} \mathrm{l}$ in water volume, and the sections of these creek channels selected for data collection were 3 to $5 \mathrm{~m}$ wide with a depth of 1.5 to $2.5 \mathrm{~m}$. Creek pairs joined at a confluence to create secondary creeks, but primary creek watersheds affected by treatments were large $\left(\sim 60000 \mathrm{~m}^{2}\right)$ and sampling areas were distant from each other $(200 \mathrm{~m}$ to $1 \mathrm{~km})$. All creeks were characterized by $3 \mathrm{~m}$ tidal fluxes and distinct habitat and biotic zonation. The creeks had similar macroinfauna (predominately annelid) species compositions, and the density of individual species differed little between creeks (i.e. low large-scale spatial variability) (Johnson et al. 2007). The physical attributes of the creeks were similar and there was no difference among creeks in terms of sediment-dwelling algal biomass or infaunal abundance before treatments were applied (Deegan et al. 2007, Johnson et al. 2007). All creeks were replete with mosquito ditches, which are small, linear, steep-sided cuts that connect perpendicular to the tidal creeks. Ditches ranged from 0.25 to $1.0 \mathrm{~m}$ in width and had steep vertical walls typically to a depth of 0.5 to $1.0 \mathrm{~m}$. Marsh ditches have been little studied, but have been determined to be important for killifish foraging (Allen et al. 1994). In the present study we discuss 3 habitat types: (1) 'creek-bank Spartina alterniflora', a 2 to $3 \mathrm{~m}$ swath of $S$. alterniflora monoculture at the edge of the marsh platform; (2) 'creek wall', a vertical habitat immediately adjacent to the creek-bank $S$. alterniflora in the main creek channels; and (3) 'ditch wall', a vertical habitat in mosquito ditches.

Treatments. To simulate nutrient loading, nutrients were added in solution to the creek water column with a targeted concentration of $70 \mu \mathrm{M} \mathrm{NaNO}{ }_{3}^{-}$and $6 \mu \mathrm{M}$ $\mathrm{PO}_{4}{ }^{+}$with each flooding tide from 15 May to 1 October. This timeframe coincided with nutrient enrichment from residential fertilizer runoff possibly being at its highest. In 2005, two secondary creeks were fertilized near the confluence of their 2 primary creeks ( 4 fertil- 
ized primary creeks), and 4 primary creeks received no nutrient enrichment (see Deegan et al. 2007 for details). Fundulus heteroclitus was reduced in abundance by $60 \%$ in 2 fertilized and 2 non-fertilized primary creeks by stretching $7 \mathrm{~mm}$ mesh Vexar across the creek channel to exclude fish and using killifish-selective traps behind the exclusion. Because of the size of each creek system and the large area of habitat affected by our treatments, each creek was considered an independent experimental unit. Four treatment combinations with replication $(\mathrm{N}=2)$ were implemented in 2005: ambient fish/ambient nutrients (control), ambient fish/nutrient additions, low fish/nutrient additions, and low fish/ambient nutrients. We manipulated only one creek in each treatment (i.e. no replication) in 2006 because maintenance and sampling of such large-scale treatments is expensive and labor intensive.

Epifauna collection. To quantify the response of saltmarsh epifauna to fish reduction and nutrient addition, passive collectors (litterbags; after Fell et al. 1998) were deployed in the creek-bank Spartina alterniflora habitat for $2 \mathrm{wk}$ in all treatment creeks in 2005 and 2006. Each litterbag $(29 \times 13.5 \mathrm{~cm}, 5 \mathrm{~mm}$ Delta weave mesh) was filled with 15 to $20 \mathrm{~g}$ of dried S. alterniflora leaves and stems. These are passive collectors that allow epifauna to enter and exit through the mesh for the time of deployment. We did not attempt to estimate the absolute abundance (no. $\mathrm{m}^{-2}$ ) of epifauna from litterbags, but instead examined the abundance patterns of epifauna per bag among treatments, and assumed that higher absolute abundance proportionately leads to higher litterbag catches (Fell et al. 1998, Warren et al. 2002, Fell et al. 2003). At low tide, 8 to 10 litterbags (held with garden staples flush with surface) were haphazardly placed among the stems of creek-bank $S$. alterniflora plants within 50 to $100 \mathrm{~m}$ from the confluence of primary creeks. We recognize some biases of the litterbags as epifaunal collectors; some visually abundant species such as the coffee bean snail, Melampus bidentata (D. S. Johnson pers. obs.) did not enter the bags, and the mesh size may have precluded collection of unusually large amphipods. Litterbag collection dates were similar in the 2 years: 8 July and 12 August 2005 and 15 July and 21 August 2006.

At the time of retrieval, each litterbag was placed individually into a $4 \mathrm{l}$ plastic bag to minimize escape of epifauna, and then placed in a cooler for transport. In the laboratory, the contents of each litterbag were emptied into the plastic bag, with care taken not to allow active epifauna to escape. A 50\% ethanol and Rose Bengal solution was then added. After at least $2 \mathrm{~d}$, litter was rinsed over a $0.5 \mathrm{~mm}$ sieve and all animals were collected using forceps and a magnifying lens. Animals were identified to lowest practical taxon, enumerated, and preserved in 95\% ethanol. Amphi- pods identified as Uhlorchestia spartinophila in the present study were a mixture of $99.9 \%$ U. spartinophila and $0.1 \%$ Orchestia grillus based on subsamples that were fully identified.

We noted unexpectedly high densities of Uhlorchestia spartinophila on the steep, almost vertically oriented, algae-covered (consisting of filamentous algae, macroalgae, and epiphytic diatoms) creek-wall habitat adjoining the Spartina alterniflora habitat, and on the walls of mosquito ditches (hereafter ditch walls) in some creek systems near the end of the field season in 2005 (D. S. Johnson pers. obs.). Many of these amphipods were orange in color. Orange color morphs indicate trematode parasitism that may alter amphipod behavior (Bousfield $\&$ Heard 1986) and increase movement onto the wall habitats. We conducted direct counts of amphipods on the creek and ditch walls in 2006 to determine their use of these habitats in experimental creeks. For this purpose, thirty $0.25 \mathrm{~m}^{2}$ quadrats were haphazardly placed (at least $2 \mathrm{~m}$ apart) in each treatment between 50 to 200 $\mathrm{m}$ from the confluence of the primary creeks. For ditch walls, 10 quadrats were placed haphazardly within a $50 \mathrm{~m}$ segment of ditch in 3 of the ditches found in each treatment for a total of 30 per treatment. Amphipod counts were conducted after at least $1 \mathrm{~d}$ after quadrat placement to minimize disturbance. Two color morphs - orange and brown - were found on the wall habitats and the frequency of each morph was quantified. The percent cover of algae was determined visually within each quadrat. All counts and percent cover estimates were conducted by the same investigator (D. S. Johnson).

We visually censused birds in the creek and ditch channels (which include wall habitats and adjacent mudflats). For creek channels, this was accomplished by walking $150 \mathrm{~m}$ along the platform edge at low tide; each bird seen in the creek channels was identified and counted. All creek sections had similar widths (3 to $5 \mathrm{~m}$ ) and foraging areas for birds. When birds were flushed and landed further down the creek channel, the bird was not counted again. For bird counts in ditch channels, $50 \mathrm{~m}$ of 3 ditches within a treatment were walked. Four bird walks were conducted between 17 August and 17 September 2006. Each creek walk and ditch walk (pooled from 3 ditches) took approximately $15 \mathrm{~min}$. To determine if birds consumed amphipods, direct consumption of amphipods (i.e. predation) by birds in the creek wall habitats in Sweeney Creek was monitored visually using binoculars during low tide on 3 separate days (30 August, 5 and 6 September 2006; D. S. Johnson) for a total of 6 h. Simultaneously, amphipods were observed to note movement between the creek bank and creek wall habitats.

Statistical analyses. Litterbag abundances of epifauna were averaged within each treatment for each time-point and analyzed using a 2-way ANOVA with 
fish and nutrients as factors. Litterbag abundances and quadrat densities from the 2006 creek wall data were analyzed in an unreplicated 2-way ANOVA, thus no interaction term was available. Quadrat densities from ditch walls were analyzed using a 1-way ANOVA with 4 treatment levels, with ditches nested within treatment. Bird sightings from 2006 were examined in a repeated measures 2-way ANOVA. Percent algal cover was examined using $t$-tests between the 2 nutrient treatments. All analyses were conducted in SigmaStat (v. 3.1) and transformations were applied to approximate normality and homogeneity of variances for quadrat densities and bird abundances.

\section{RESULTS}

\section{Litterbag collections}

In total, 5801 individual epifauna were collected, representing at least 14 epifaunal species. For samples from 2005, hydrobiid snails Hydrobia spp. (15\% of total abundance) and the amphipod Uhlorchestia spartinophila (76\% of total abundance) were selected for analysis because they represented major constituents of the epifauna community (Table 1). In 2006, $U$. spartinophila was again examined; however, fewer than 0.35 hydrobiid snails were collected per litterbag (compared to 4.6 per litterbag in 2005), a number judged to be too low in abundance for analysis.

Table 1. Relative contribution (\%) of epifauna to the community in the creek-bank Spartina alterniflora habitat in the Plum Island Estuary, MA. Percentages are a composite of all litterbag samples taken per year. A: amphipod; C: chelicerate; I: isopod; In: insect; S: snail

\begin{tabular}{|lcr|}
\hline Taxon & 2005 & 2006 \\
\hline Uhlorchestia spartinophila (A) & 75.5 & 65.7 \\
Orchestia grillus (A) & - & 0.5 \\
Gammarus sp. (A) & 4.2 & 21.7 \\
Philosica vittata (I) & 0.0 & 0.7 \\
Hydrobia spp. (S) & 15.4 & 1.7 \\
Mites (C) & 1.0 & 2.5 \\
Spiders (C) & 1.2 & 2.0 \\
Psuedoscorpion (C) & 0.3 & 0.4 \\
Tabanus sp. larvae (In) & 1.8 & 1.1 \\
Other insect larvae (In) & 0.1 & 2.0 \\
Beetles (In) & 0.3 & 1.4 \\
Collembola (In) & 0.0 & 0.1 \\
\hline
\end{tabular}

There were no treatment effects on hydrobiid snails or Uhlorchestia spartinophila in July 2005 (Table 2). In August 2005, fish reductions significantly increased hydrobiid snail abundance (fish main effect: $\mathrm{p}=0.044$ ) and treatments interacted on $U$. spartinophila litterbag abundances (fish $\times$ nutrients: $p=0.049$ ) with litterbag abundances lower than expected by an additive response (i.e. an antagonism) (Table 2).

In both July and August 2006 there was no significant main effect of treatments on litterbag amphipods (Table 2). The lack of creek-scale replicates prohibited us from examining interactions in 2006; however, the observed low abundance in combined treatments (Fig. 1) suggests that an antagonistic interaction may have occurred on amphipods when treatments were combined, as was shown in 2005.

\section{Quadrat densities}

In the ditch walls, a significant treatment effect was found (1-way ANOVA, p=0.0007, Table 2) and amphi- 
Table 2. Uhlorchestia spartinophila and Hydrobia spp. Results from 2-way ANOVAs for dominant taxa in the creek-bank Spartina alterniflora habitat. In 2006, too few snails were collected and were not analyzed; U. spartinophila 2006 data was analyzed in an unreplicated 2-way ANOVA. N: Nutrient treatments; F: fish treatments; nd: not determined

\begin{tabular}{|c|c|c|c|c|c|c|c|c|c|}
\hline \multirow[t]{3}{*}{ Taxon } & \multirow[t]{3}{*}{ Treatment } & \multicolumn{4}{|c|}{2005} & \multicolumn{4}{|c|}{-2006} \\
\hline & & \multicolumn{2}{|c|}{ July } & \multicolumn{2}{|c|}{ August } & \multicolumn{2}{|c|}{ July } & \multicolumn{2}{|c|}{ August } \\
\hline & & $\mathrm{df}$ & $\mathrm{p}$ & df & $\mathrm{p}$ & $\mathrm{df}$ & $\mathrm{p}$ & $\mathrm{df}$ & $\mathrm{p}$ \\
\hline \multirow[t]{3}{*}{ Uhlorchestia spartinophila } & $\mathrm{N}$ & 1,4 & 0.085 & 1,4 & 0.617 & 1,1 & 0.585 & 1,1 & 0.368 \\
\hline & $\mathrm{F}$ & 1,4 & 0.706 & 1,4 & 0.319 & 1,1 & 0.852 & 1,1 & 0.868 \\
\hline & $\mathrm{N} \times \mathrm{F}$ & 1,4 & 0.686 & 1,4 & 0.049 & nd & nd & nd & nd \\
\hline \multirow[t]{3}{*}{ Hydrobia spp. } & $\mathrm{N}$ & 1,4 & 0.307 & 1,4 & 0.089 & nd & nd & nd & nd \\
\hline & $\mathrm{F}$ & 1,4 & 0.115 & 1,4 & 0.044 & nd & nd & nd & nd \\
\hline & $\mathrm{N} \times \mathrm{F}$ & 1,4 & 0.549 & 1,4 & 0.686 & nd & nd & nd & nd \\
\hline
\end{tabular}

pods occurred in the ditch walls with combined treatments an average of $50 \times$ more than in control treatments (least square means; ambient fish/ambient nutrients vs. low fish/nutrient additions: 0.2 vs. 8.1 amphipods $\left.\mathrm{m}^{-2}, \mathrm{p}=0.0005\right)$. Additionally, amphipod densities in combined treatments in the ditch wall were $>10$-fold higher than densities for either treatment in the creek wall (Fig. 2). Treatments did not statistically influence the densities of amphipods in the creek wall habitats. An average of $7.6 \times$ more amphipods was found in the creek walls in the nutrient treatments, and the highest average densities occurred in combined treatments $\left(0.7\right.$ amphipods $\mathrm{m}^{-2}$ ). Overall, orange color morphs constituted $0 \%$ of the amphipods in the ambient nutrient creeks and $97 \%$ of the amphipods in the nutrient creeks, indicating higher rates of parasitism with nutrient additions.

\section{Bird surveys and amphipod movement}

Thirty-eight of the 39 birds observed in the creek systems examined were the semipalmated sandpiper Calidris pusilla, a migratory shorebird. One seaside sparrow Ammodramus maritimus was observed. A significant treatment interaction occurred (fish $\times$ nutrients: $p=0.009$, Table 3 ), with $30 \times$ more birds seen in combined treatments than in the controls in creek channels (Fig. 2). No birds were observed in the ditches of non-nutrient creeks, and an average of $\sim 2$ birds per walk were observed in nutrient ditches. C. pusilla was observed foraging (i.e. probing the sediment with their beaks) when in creeks; $20 \%$ of their time was spent on the creek wall, and the remainder was spent on mudflats. Birds were observed feeding upon amphipods on 2 occasions on the creek wall. Three instances of movement of amphipods from the creek-bank to the creek-wall habitats were observed.
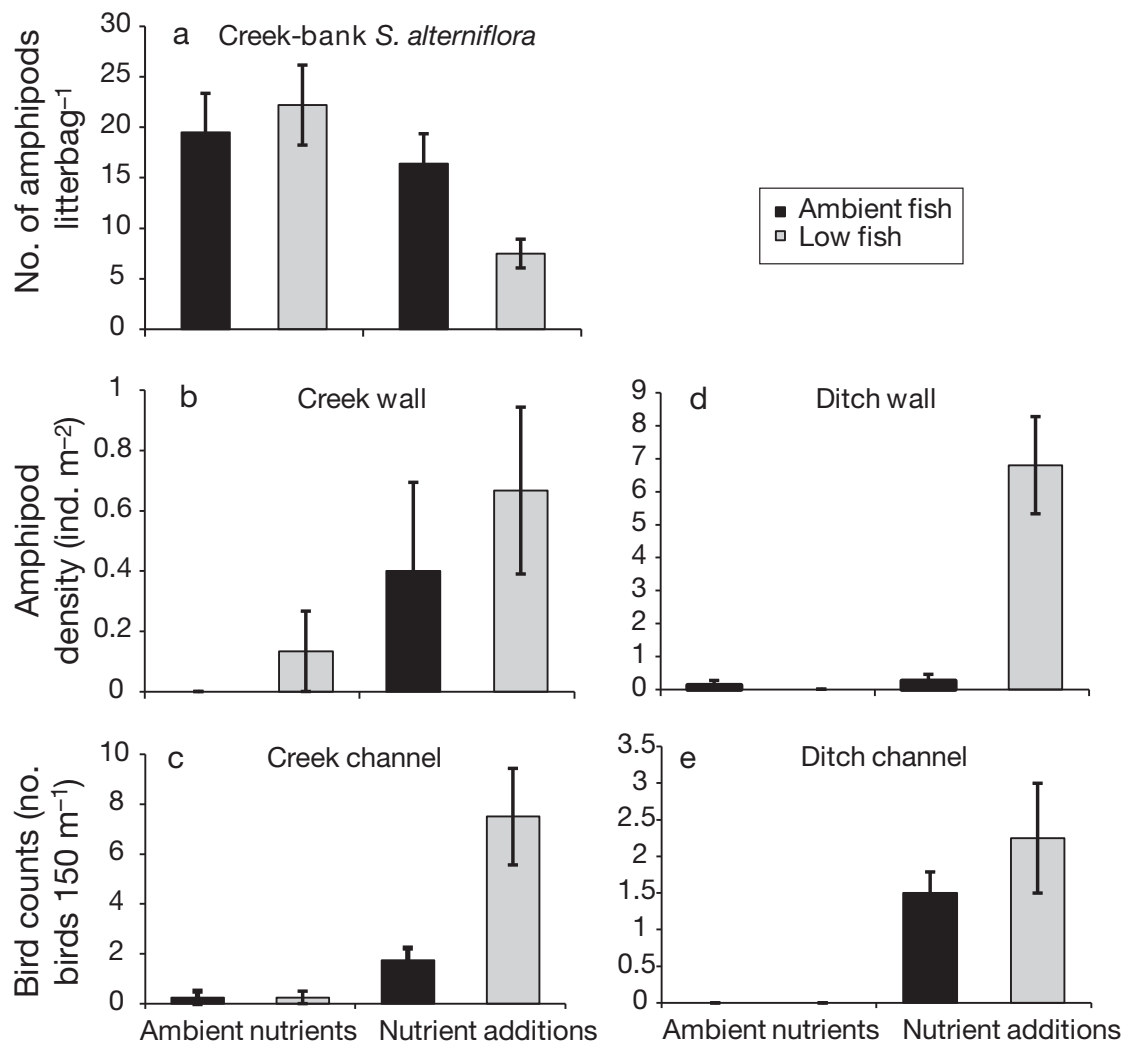

Fig. 2. Uhlorchestia spartinophila and Calidris pusilla. (a) U. spartinophila (amphipods) collected in litterbags for creek-bank Spartina alterniflora habitat and amphipod density for the (b) adjoining creek-wall habitat and (d) ditch wall habitat. C. pusilla (birds) counted in the (c) main creek channel and (e) ditch channels at low tide over $150 \mathrm{~m}$. All collections are from August 2006 
Table 3. Uhlorchestia spartinophila and Calidris pusilla. Results of an unreplicated 2-way ANOVA for quadrat densities of the amphipod U. spartinophila in vertical wall habitats (creek and ditch) and from a repeated measures 2-way ANOVA on sightings of the shorebird $C$. pusilla in 2 channel types (creek and ditch). N: nutrient treatments; F: fish treatments; nd: not determined

\begin{tabular}{|lccccc|}
\hline \multirow{2}{*}{ Taxon } & \multirow{2}{*}{ Treatment } & \multicolumn{2}{c}{ Creeks } & \multicolumn{2}{c|}{ Ditches } \\
& & $\mathrm{df}$ & $\mathrm{p}$ & $\mathrm{df}$ & $\mathrm{p}$ \\
\hline U. spartinophila & $\mathrm{N}$ & 1,1 & 0.210 & $\mathrm{nd}$ & $\mathrm{nd}$ \\
& $\mathrm{F}$ & 1,1 & 0.578 & $\mathrm{nd}$ & $\mathrm{nd}$ \\
C. pusilla & $\mathrm{N}$ & 1,3 & 0.002 & 1,3 & 0.022 \\
& $\mathrm{~F}$ & 1,3 & 0.093 & 1,3 & 0.391 \\
& $\mathrm{~N} \times \mathrm{F}$ & 1,3 & 0.009 & 1,3 & 0.391 \\
\hline
\end{tabular}

\section{Percent algal cover}

Nutrient additions significantly increased algal cover by 1.5 -fold on creek walls (mean $\pm \mathrm{SE}$; ambient nutrients: $39.3 \pm 3.7 \%$; nutrient additions: $58.8 \pm 3.7 \%$; $t$-test, $\mathrm{p}<0.001)$. Algal cover was only slightly and non-significantly higher on ditch walls in nutrient creeks than in ambient creeks (ambient nutrients: $48.0 \pm 3.6 \%$; nutrient additions: $53.8 \pm 3.4 \%$; $t$-test, $\mathrm{p}>$ $0.05)$.

\section{Response of other trophic levels}

Here we summarize the responses of other trophic levels that are potentially relevant to understanding the effects on epifauna. The effect of treatments on other taxa (e.g. killifish and benthic microalgae) relevant to explaining potential top-down and bottom-up effects on epifauna are detailed for the first $2 \mathrm{yr}$ of experimental treatments in Deegan et al. (2007). Killifish abundance varied temporally and spatially in experimental creeks. Despite the variation, fish removal did lead to significant reductions in killifish abundance (see Deegan et al. 2007, their Fig. 4). Killifish reduction did not lead to increased grass shrimp density (Deegan et al. 2007), but did lead to enhanced growth of shrimp (Johnson 2008), possibly due to increased carnivory by shrimp on infaunal annelids (Galván 2008). Prior to treatments, within-habitat benthic microalgae (BMA) biomass was similar among creeks, although inter-habitat differences occurred. Significant effects of treatments on BMA biomass were detected only in the second year of treatment in Sweeney and West Creeks, in which biomass increased synergistically (Deegan et al. 2007, their Fig. 7). Johnson \& Fleeger (unpubl.) found that treatments did not influence the abundance, diversity, or community composition of infaunal annelids after $3 \mathrm{yr}$, nor did treatments alter the abundance or distribution of Spartina alterniflora or S. patens over the course of manipulations (Miller 2006).

\section{DISCUSSION}

We observed significant predation effects on hydrobiid snails, a common constituent of killifish gut contents (Allen et al. 1994, Fell et al. 1998), in the creekbank Spartina alterniflora habitat in August 2005, and although not significant, this trend was similar in July 2005. Hydrobiids are known to disperse using a flotation device (Levinton 1979), but we know of no evidence that dispersal behavior is altered by the presence of predators. Given their small size and limited ability to escape predation, we consider changes in litterbag abundance for hydrobiid snails were due to direct consumptive effects of killifish.

The results of top-down and bottom-up manipulations on talitrid amphipods were complex. In summary: (1) nutrient enrichment and predator removal alone consistently but only modestly affected amphipod abundance on creek banks (small, non-significant increases were noted over 2 field seasons), (2) significant interaction between the 2 treatments was observed that, coupled with changes in amphipod abundance on adjacent creek or ditch walls, suggests that amphipod utilization of wall habitats increased when treatments were applied, and (3) amphipod abundance on creek-wall habitats may have been influenced by the increased presence of a predatory bird (Calidris pusilla) in nutrient treatments.

The combined nutrient enrichment and predator removal led to significantly lower amphipod abundance than expected (an antagonism) in creek-bank habitats (Fig. 1). This finding was confirmed statistically in one field season when replicate creeks were used, and was paralleled on 2 occasions in a different field season without replication. We noted simultaneously that amphipod densities increased on the surface of creek and ditch walls where treatments were applied (Fig. 2), suggesting amphipods may have moved to wall habitats from the creek bank and that this movement contributed to the lower than expected abundance on creek banks. Amphipod abundance was significantly elevated on ditch walls with combined nutrient enrichment and fish reduction (where abundances were increased at least 50-fold relative to control treatments). Similar but non-significant trends were observed on creek walls. Uhlorchestia spartinophila is typically associated with creek-bank Spartina alterniflora habitats (Covi \& Kneib 1995), and its occurrence on exposed wall habitats has not been reported previously. The observation that amphipod habitat uti- 
lization was altered by treatments was unexpected, and suggests that treatments may have elicited effects not detectable through monitoring a single habitat, even if that habitat is the principal habitat for the species of interest.

We also noted increased densities of sandpipers in the creeks with nutrient enrichment (but without replication in 2006) (Fig. 2). Sandpipers were observed on the marsh platform (the expansive, elevated area with ponds, dominated by $S$. patens and landward of creekbank Spartina) of both ambient nutrient and nutrientenriched creeks, but were sighted more frequently in the nutrient-enriched creek channel. Calidris pusilla sightings in ditches were fewer overall but exhibited the same trend as creek channels: no birds were sighted in the ambient nutrient ditches, and an average of 2 birds were sighted in the nutrient enrichment ditches. Thus, sandpiper abundance was higher with increased amphipod density, an observation that suggests there is a direct or indirect interaction between the 2 taxa, e.g. birds might be attracted to creek beds to prey on amphipods that migrate to wall habitats.

The 10 -fold difference in amphipods observed be tween the creek and ditch wall habitats with nutrient enrichment may be explained by the higher occurrence of sandpipers in creek channels than in ditch channels. Creek walls have small outcroppings on which birds may perch, facilitating foraging for infauna (e.g. annelid worms) and epifauna (e.g. amphipods). Sandpipers were observed over a $150 \mathrm{~m}$ linear distance, and an average of 6 more birds were seen in creeks compared to ditches over the same distancetime period. If amphipods are standardized to the same linear distance $(150 \times 1 \mathrm{~m})$, then an estimated 90 amphipods were on the creek wall and 1020 were on the ditch wall. Thus, for the large difference in amphipod densities between habitats to occur, 6 birds would have to consume 930 amphipods (or each bird consumes 155 amphipods) if amphipods visit creek and ditch walls equally. Sandpiper abundances peak between mid-July to mid-August, during which time direct counts were conducted. Using a $30 \mathrm{~d}$ time period, each bird would then have to consume 5.2 amphipods $\mathrm{d}^{-1}$, and using a foraging period (low tide) per day of $3 \mathrm{~h}$, each bird would have to consume at least 1.7 amphipods $\mathrm{h}^{-1} \mathrm{~d}^{-1}$. Anecdotal observations suggest sandpipers can consume up to 4 amphipods $\mathrm{h}^{-1}$ on creek-wall habitats at low tide (D. S. Johnson pers. obs.). Thus, it is plausible that bird predation over the course of the summer season is adequate to limit amphipod densities on creek walls at the end of the season. We suggest that sandpipers may replace killifish as the principal predator of amphipods when nutrients are increased, exerting top-down control on amphipods in creek channels at low tide. Alternatively, the difference in amphipod densities between the 2 wall types may result from increased reproduction and/or recruitment to preferred ditch walls in nutrientenriched creeks. However, the mechanism of such an increase is difficult to ascertain based on our results and remains uncertain.

Although we have no measures of the magnitude of amphipod dispersal between creek-bank and creek-wall habitats, direct observations suggest amphipods do move between habitats (D. S. Johnson unpubl. data). Additionally, the occurrence of talitrid amphipods on creek and ditch walls was much higher in nutrient-enriched creeks, suggesting inter-habitat movements were increased. Nutrient enrichment may increase amphipod movement due to enriched food supply (Kraufvelin et al. 2006). Isotopic evidence from PIE (Galván 2008) suggests that talitrid amphipods forage for algae while on creek and ditch walls during the summer months. Our visual inspection of creek walls found increased algal abundance in the creeks with nutrient addition. Further, benthic algae increased synergistically in creeks with nutrient enrichment and fish reduction during the time of our studies (Deegan et al. 2007). Predator release (Vince et al. 1976) and density-dependent migration (Van Dolah 1978) may also stimulate amphipod changes in habitat utilization.

Killifish reduction would not be expected to stimulate amphipods to move to a more open habitat (i.e. creek walls without vegetation), which would in turn increase vulnerability to predation (i.e. amphipods on the creek wall may be more susceptible to predation from remaining killifish during high tide or from birds at low tide). Movement of amphipods under conditions of nutrient enrichment in the present study may be parasiteinduced. For example, infaunal amphipods Corophium volutator in the Bay of Fundy parasitized by the nematode Skrjabinoclava morrisoni crawl more actively on the sediment surface, thereby making them more susceptible to predation by Calidris pusilla, the parasite's final host (McCurdy et al. 1999). Hydrobiid snails are the initial host of the microphallid trematode Levinseniella byrdi, and talitrid amphipods (including Uhlorchestia spartinophila) and shorebirds (including Calidris pusilla) are the intermediate and the final hosts in salt marshes (Bousfield \& Heard 1986). Amphipods parasitized by L. byrdi develop a bright orange color due to the dissociation of carotenoids from proteins and do not exhibit strong negative phototaxis as do unparasitized individuals (Bousfield \& Heard 1986). These trematode-induced trait modifications (behavior and color) increase amphipod vulnerability to predation by shorebirds, including Calidris pusilla. In 2006, $97 \%$ of amphipods found on the wall habitats of the nutrientenriched creek were bright orange, and trematode metacercariae (Levinseniella sp.) were found in several 
orange specimens examined (R. W. Heard pers. comm.), suggesting that $U$. spartinophila on walls were heavily parasitized. Parasitized amphipods may move into more exposed habitats such as the creek walls where they are subsequently preyed upon by Calidris pusilla or other shorebirds (e.g. seaside sparrows).

The mechanism explaining the increased incidence of parasitized amphipods under nutrient enrichment is unclear but could be associated with factors that influence survivorship or growth of hydrobiid snails (the first host) or the intermediate stages (cecariae) of the parasite that infect Uhlorchestia spartinophila. Hydrobiid snails were increased by fish removals but not by nutrient addition, so increases in snail abundance cannot explain increased amphipod infection. Alternatively, infected birds may be attracted to fertilized creeks for some other reason (e.g. another prey species becomes abundant due to fertilization), and the increased frequency of use of fertilized creeks by infected birds may lead to an increase in the infection rate of amphipods. Our results suggest that top-down and bottom-up forces acted in concert and behavioral effects were important in modifying predator-prey interactions. Previous examinations of the saltmarsh benthos which have combined top-down/bottom-up manipulations on infauna (typically less motile than epifauna) have typically found no interactive effects (Posey et al. 1999, 2002). Assuming amphipods are migrating, the interactive effects we found for epifauna may be a function of changes in behavior and motility. Alternatively, the interactive effects of treatments on amphipods found in the creek-bank Spartina alterniflora habitat may be explained by increased predation by other nektonic predators, such as grass shrimp Palaemonetes pugio. Killifish and grass shrimp constitute $98 \%$ of the nekton community, and grass shrimp may increase predation on infaunal annelids when killifish are removed (Galván 2008, Johnson 2008). However, it is unlikely that grass shrimp increase predation on large, epibenthic prey such as amphipods.

Our results suggest that single-factor experiments are poor predictors of multifactor effects for mobile species such as amphipods. It is possible that stronger single-factor effects occurred but were difficult to detect due to at least 3 complicating factors in this system. First, single-factor effects are difficult to detect for mobile epifauna because of their movement between habitats, and thus knowledge of true effects requires a landscape or multiple habitat approach. Second, even with the knowledge of total population effects (i.e. all habitats combined), top-down effects may be difficult to identify due to the functional redundancy between birds and fish, wherein birds exhibit compensatory predation when fish are removed. Third, the low replication ( $\mathrm{N}=1$ to 2 ) in the present study made detection of effects problematic (e.g. see the large error bars in Figs. 1 \& 2); however, ecologically relevant trends were observed even if statistically significant treatment effects were not detected. Additionally, bird abundances were observed in unreplicated systems and are therefore confounded within creeks, and variation in abundances may or may not be attributable to treatments. To increase predictive power of single-factor and/or interactive effects, future investigations should strive to increase whole-ecosystem replication and integrate multiple-habitat observations over a broad range of saltmarsh fauna (such as parasites and birds) into sampling protocols.

Our work shows that large-scale experiments can aid in the understanding of anthropogenic effects. Although our replication of experimental units was low, we found similar responses of epifauna to treatments in temporally replicated observations within seasons and between field seasons, suggesting that the patterns we observed are repeatable and related to the treatments. Our results also add to the growing body of evidence that the traits of prey, specifically behavior, may play an important role in ecological interactions (Werner \& Peacor 2003). The detection of a potential functional redundancy between predators (fish and birds) in this system was enhanced by the large scale of the present study. Thus, focus on single-habitat or small-scale manipulations may make the process of detecting effects on mobile fauna (even small fauna) problematic. Future work is planned to examine some of the hypotheses posed above, including treatment effects on amphipod incidence of parasitism. We feel the ability to detect the ecological consequences of anthropogenic activities is greatly enhanced by examining effects across landscapes (i.e. multiple habitats) and at large scales.

Acknowledgements. We thank C. Bethony, K. Galván and B. Jessen for field assistance. R. W. Heard assisted with trematode identification. Comments from M. Grippo, K. Harms and C. Kennedy improved this manuscript. This material is based upon work supported by the National Science Foundation under Grant Nos. 0213767 and 9726921. Any opinions, findings, and conclusions or recommendations expressed in this material are those of the authors and do not necessarily reflect the views of the National Science Foundation.

\section{LITERATURE CITED}

Allen EA, Fell PE, Peck MA, Gieg JA, Guthke CR, Newkirk MD (1994) Gut contents of common mummichogs, Fundulus heteroclitus L., in a restored impounded marsh and in natural reference marshes. Estuaries 17:462-471

> Bousfield EL, Heard RW (1986) Systematics, distributional ecology, and some host-parasite relationships of Uhlorchestia uhleri (Shoemaker) and Uhlorchestia spartinophila, new species (Crustacea, Amphipoda), endemic to salt marshes of the Atlantic coast of North America. J Crustac Biol 6:264-274 
Covi MP, Kneib RT (1995) Intertidal distribution, population dynamics and production of the amphipod Uhlorhcestia spartinophila in a Georgia, USA, saltmarsh. Mar Biol 121: $447-455$

Crowder LB, Squires DD, Rice JA (1997) Nonadditive effects of terrestrial and aquatic predators on juvenile estuarine fish. Ecology 78:1796-1804

Deegan LA, Bowen JL, Drake D, Fleeger JW and others (2007) Susceptibility of salt marshes to nutrient enrichment and predator removal. Ecol Appl 17:S42-S63

Duffy JE, Hay ME (2000) Strong impacts of grazing amphipods on the organization of a benthic community. Ecol Monogr 70:237-263

$>$ Fell PE, Weissbach SP, Jones DA, Fallon MA and others (1998) Does invasion of oligohaline tidal marshes by reed grass, Phragmites australis (Cav) Trin ex Steud, affect the availability of prey resources for the mummichog, Fundulus heteroclitus L.? J Exp Mar Biol Ecol 222:59-77

Fell PE, Warren RS, Light JK, Rawson RL, Farley SM (2003) Comparison of fish and macroinvertebrates use of Typha angustifolia, Phragmites australis, and treated Phragmites marshes along the Lower Connecticut River. Estuaries 26: $534-551$

Fleeger JW, Johnson DS, Galván KA, Deegan LA (2008) Topdown and bottom-up control of infauna varies across the saltmarsh landscape. J Exp Mar Biol Ecol 357:20-34

Galván KA (2008) Diet of saltmarsh consumers. PhD dissertation, Louisiana State University, Baton Rouge

> Hairston NG, Smith FE, Slobodkin LB (1960) Community structure, population control and competition. Am Nat 94: 421-425

Johnson DS (2008) Trophic control of saltmarsh invertebrates. $\mathrm{PhD}$ dissertation, Louisiana State University, Baton Rouge

Johnson DS, Fleeger JW (in press) The effect of nutrient enrichment and predator removal on macroinfauna in a Massachusetts salt marsh: a four-year study. J Exp Mar Biol Ecol

Johnson DS, Fleeger JW, Galván KA, Moser EB (2007) Worm holes and their space-time continuum: spatial and temporal variability of macroinfaunal annelids in a northern new England salt marsh. Estuar Coast 30:226-237

Kneib RT (1982) Habitat preference, predation, and the intertidal distribution of gammaridean amphipods in a North Carolina saltmarsh. J Exp Mar Biol Ecol 59:219-230

Kraufvelin P, Salovius S, Christie H, Moy FE, Karez R, Pedersen MF (2006) Eutrophication-induced changes in benthic algae affect the behaviour and fitness of the marine amphipod Gammarus locusta. Aquat Bot 84:199-209

Lapointe BE (1997) Nutrient thresholds for bottom-up control

Editorial responsibility: Robert Feller,

Columbia, South Carolina, USA of macroalgal blooms on coral reefs in Jamaica and southeast Florida. Limnol Oceanogr 42:1119-1131

Levinton JS (1979) The effect of density upon deposit-feeding populations: movement, feeding and floating of Hydrobia ventrosa Montagu (Gastropoda: Prosobranchia). Oecologia 43:27-39

> McCurdy DG, Forbes MR, Boates JS (1999) Evidence that the parasitic nematode Skrjabinoclava manipulates host Corophium behavior to increase transmission to the sandpiper, Calidris pusilla. Behav Ecol 10:351-357

Miller EE (2006) Experimental nutrient enrichment of a New England salt marsh: plant productivity and community composition responses. MS thesis, Connecticut College, New London

Posey MH, Alphin TD, Cahoon L, Lindquist D, Becker ME (1999) Interactive effects of nutrient additions and predation on infaunal communities. Estuaries 22:785-792

> Posey MH, Alphin TD, Cahoon LB, Lindquist DG, Mallin MA, Nevers MB (2002) Top-down versus bottom-up limitation in benthic infaunal communities: direct and indirect effects. Estuaries 25:999-1014

> Power MB (1992) Top-down and bottom-up forces in food webs: Do plants have primacy? Ecology 73:733-746

Russell BD, Connell SD (2005) A novel interaction between nutrients and grazers alters relative dominance of marine habitats. Mar Ecol Prog Ser 289:5-11

Sarda R, Foreman K, Werme CE, Valiela I (1998) The impact of epifaunal predation on the structure of macroinfaunal invertebrate communities of tidal saltmarsh creeks. Estuar Coast Shelf Sci 46:657-669

- Van Dolah RF (1978) Factors regulating the distribution and population dynamics of the amphipod Gammarus palustris in an intertidal salt marsh community. Ecol Monogr 48: 191-217

Vince S, Valiela I, Backus N, Teal J (1976) Predation by salt marsh killifish Fundulus heteroclitus (L.) in relation to prey size and habitat structure: consequences for prey distribution and abundance. J Exp Mar Biol Ecol 23:255-266

> Warren RS, Fell PE, Rozsa R, Brawley AH and others (2002) Salt marsh restoration in Connecticut: 20 years of science and management. Restor Ecol 10:497-513

Werner EE, Peacor SD (2003) A review of trait-mediated indirect interactions in ecological communities. Ecology 84: $1083-1100$

Wilson WH (1991) The foraging ecology of migratory shorebirds in marine soft-sediment communities: the effects of episodic predation on prey populations. Am Zool 31: $840-848$

Submitted: February 13, 2008; Accepted: November 21, 2008 Proofs received from author(s): February 19, 2009 